\title{
RURAL TOURISM - EVALUATING THE QUALITY OF DESTINATION
}

Kateřina Ryglová, Ida Rašovská, Jakub Šácha ${ }^{1}$

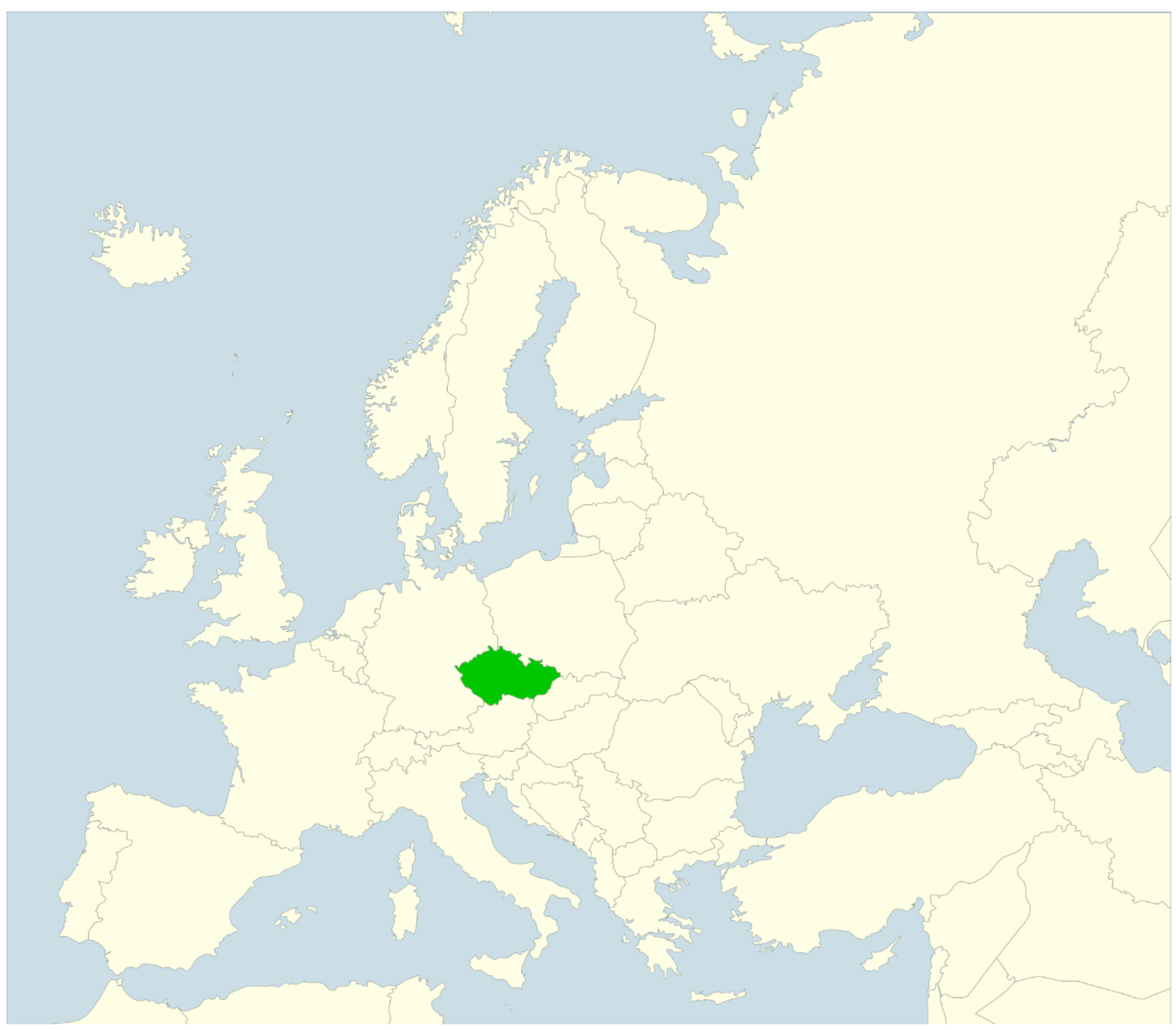

${ }^{1}$ Doc. Ing. Kateřina Ryglová, PhD., Doc. Ing. Ida Rašovská (Vajčnerová), Ing. Jakub Šácha, PhD., Faculty of Business and Economics, Mendel University in Brno, Zemědělská 1, 61300 Brno, Czech Republic; e-mails: katerina.ryglova@mendelu.cz, ida.rasovska@mendelu.cz; jakub.sacha@mendelu.cz 
Abstract: This paper concerns the topic of rural destination quality from the viewpoint of tourism development. The research exploring crucial quality factors from the viewpoint of demand is presented. Rural tourism participants attribute the highest significance to Destination cleanliness and Sense of security. The evaluation of the importance of most research quality factors is not dependent on gender and on the contrary, the importance of 16 quality factors depends on the visitor's age. In the case of the factor of "Friendly acceptance by the locals", the most significant influence on the visitor's return to the destination was confirmed. On the contrary, this impact was not proven for the factor of "Level of prices of services and goods in the destination". The research and the successive factor analysis revealed 6 dimensions representing the rural destination quality: Services, Image, Transportation, Well-being, Information/Communication and Attractions/ Experiences; Well-being was identified as the most important. This was consecutively confirmed by the analysis of the quality factors' impact on the visitor's overall satisfaction and loyalty to the destination. The research findings provide the theory with topical destination quality dimensions as well as contribute to better understanding of visitor's behavioural mechanisms in rural areas.

Key words: visitor's perception, quality of destination, rural destination, factors of quality, dimensions of quality, IPA analysis

Abstrakt: Tento přispěvek je věnován tématu kvality venkovské destinace $z$ pohledu rozvoje cestovního ruchu. Jsou zde prezentovány výsledky výzkumu zacíleného na identifikování a prozkoumání stěžejních faktorů kvality z pohledu poptávky. Nejvyšší význam účastníci cestovního ruchu na venkově přisuzují faktorům čistoty destinace a bezpečnosti $v$ destinaci. Hodnocení důležitosti většiny zkoumaných faktorů kvality (68 \%) není závislé na pohlaví, a naopak význam 16-ti faktorů kvality je závislý na věku respondenta. U faktoru kvality „prátelské prǐietí místními obyvateli“ byl prokázán nejvyšší vliv na znovu návrat návštěvníka do destinace, naopak tento vliv nebyl prokázán u faktoru „cenová úroveň zboží a služeb v destinaci“. Provedený výzkum a následná faktorová analýza odhalila 6 dimenzí reprezentující kvalitu venkovské destinace: služby, image, doprava, pohodlí (well-being), informace/komunikace, atraktivity/zážitky. Při posuzování významu dimenzí pro návštěvníka byla jednoznačně jako nejvýznamnější identifikována dimenze well-being, což bylo následně potvrzeno analýzou vlivu faktorů kvality na celkovou spokojenost návštěvníka $v$ destinaci a jeho loajalitu $k$ destinaci. Výsledky výzkumu rozšiřují teoretická východiska o hlavní dimenze kvality destinace a prohlubují poznatky spotřebitelského chování návštěvníků/účastníků cestovního ruchu ve venkovských oblastech.

\section{Introduction}

Increasing the standard of living of the inhabitants in rural areas together with mitigating regional disparities and sustainable development of the countryside belong to the most important objectives of most EU countries. In this context the efforts to diversify rural economy by means of the diversification of agricultural activities are supported. This area includes the discussion and support of activities focused on deeper and more efficient utilization of opportunities of tourism potential development in rural environment. The rural destination of tourism provides visitors with the opportunity to stay at a farm, the opportunities of walking, horse-riding and many other activities that are primarily associated with the rural environment and countryside. The OECD's view ranks also ecotourism and experience tourism among rural tourism activities. Many authors (e.g. Peláez, 2004; Simkova, 2008; Marakova, 2015) incorporate rural tourism into the group of sustainable tourism, the typical feature of which is the considerate and thoughtful relationship 
towards the nature as well as local culture, traditions, history, typical characteristics of the place and also the protection of local economy.

This paper concerns the topic of perceiving the quality of the rural destination by its visitor from the aspect of tourism development. From the marketing point of view, the destination is a complex product of tourism that has to have necessary quality and has to be managed strategically. Therefore, managing the quality of a destination can be approached through the mediation of the client/visitor when on the basis of his or her needs and requirements the offer is subsequently formed and modified. In this case, it is important to determine crucial factors that influence tourism destination quality perception. These factors can then be used as a tool for evaluating destination quality through the visitor's satisfaction.

For instance, in tourism studies, Baker and Crompton (2000), for instance, examined the relationship between quality, satisfaction and behavioural intentions and confirmed the hypothesis that perceived quality has a major influence on subsequent customer behaviour. Other studies in tourism found that tourist satisfaction directly influenced destination loyalty (Chi and Qu, 2007; Kim and Brown, 2012; Yuksel et al., 2010), some of them revealed an indirect relationship (Court and Lupton, 1997; Sonmez and Graefe, 1998), while others discivered that satisfaction exerted both direct and indirect influence on destination loyalty (Cronin et al., 2000; Taylor and Baker, 1994).

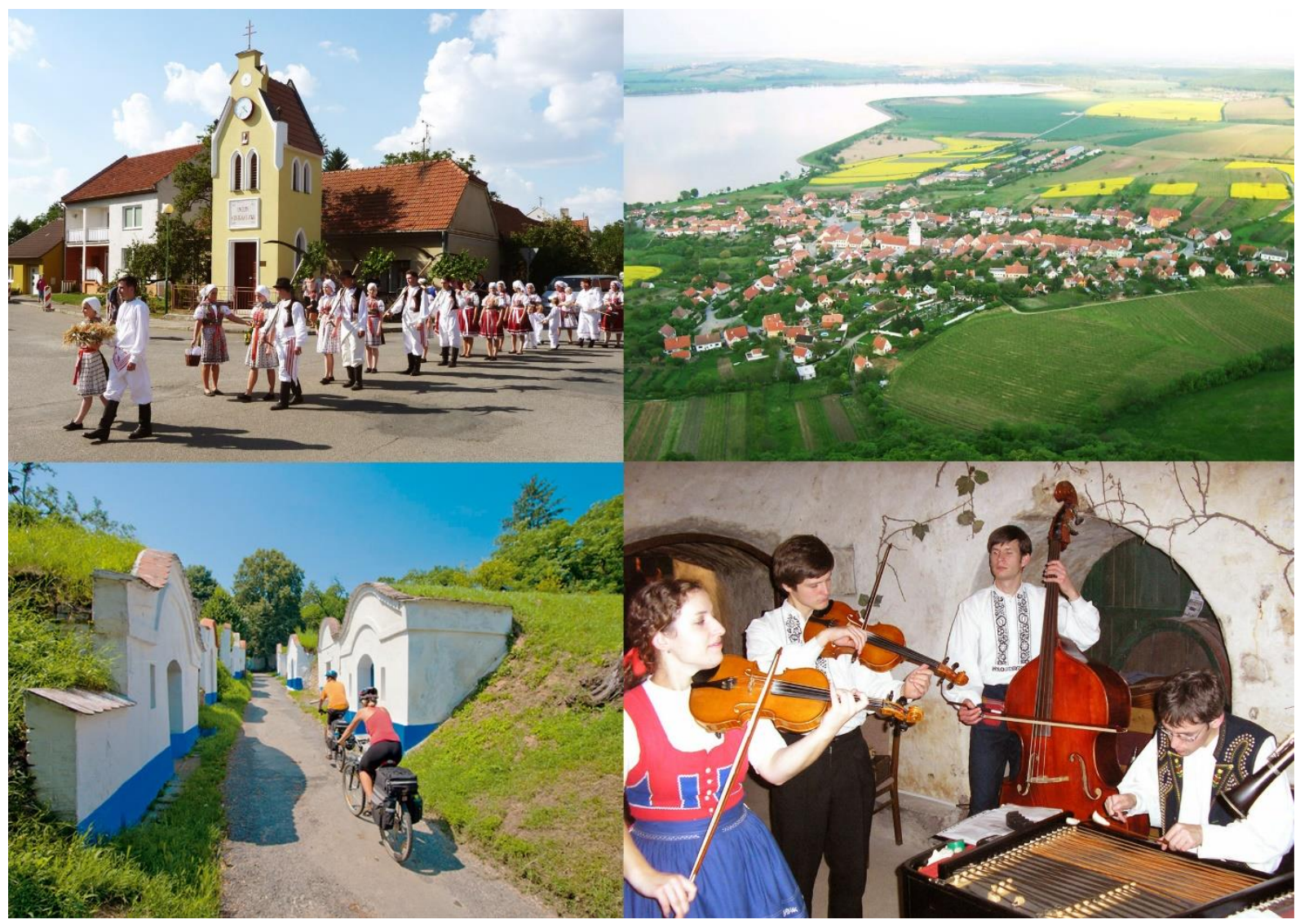

Fig 1. Tourist destination in southern Moravia are connected with the culture of wine. Source: authors

The objective of the authors was to explore the problems of perceiving quality in the rural destination, to identify key factors of quality and to explore and possibly confirm their impact on overall satisfaction and loyalty in the rural destination. The paper presents the results of the research aimed at the identification of crucial factors of destination quality perceived by the visitor who is concurrently the participant of rural tourism. Then the dependency of the revealed importance of the factors on gender and age of the visitor to the rural destination was analysed (Kruskal-Wallis test). The obtained results are used as input data for the application of Importance-Performance Analysis (IPA) that evaluates the perceived qualitative level of a rural 
destination in the Czech Republic. On the basis of IPA, the main contradictions between the actual obtained performance (the perceived level of quality of the provided service) and the attributed importance in the case of research factors in rural destinations in the Czech Republic were identified. In the next phase, the authors present the possibility of reducing the current 19 research factors into 6 dimensions representing the quality of the rural destination. When evaluating the importance of quality dimensions, the impact of the research factors on the overall satisfaction of the visitor to the rural destination and his or her loyalty to the destination was considered.

\section{Theoretical basis}

Determining and then evaluating destination quality in the context of tourism development is not an easy issue, which is confirmed by different approaches towards these terms in scientific literature (e.g. Woods and Deegan, 2003; Hudson, 2008). This fact is given by the high level of the destination complexity as well as the high level of subjectivity in the process of quality evaluation and also by the specific character of the services (in particular impalpability, transience and variability).

Bieger (2008) defines the destination as a space (region) which the visitor chooses as a target of his or her journey. It disposes of all necessary facilities for accommodation, boarding and entertainment. This way it becomes a product and a unit of economic competition that thus has to be systematically managed. According to Cho (2000), the destination is "a target place of potential clients who see the area from their points of view in relation to the content (product) and location (region) with the purpose to satisfy their needs and demands during their stays in the target area".

Buhalis (2003) defines five characteristic components of each destination:

- Attractions (a primary offer of tourism that due to its amount, quality and attractiveness activates attendance, for instance natural, cultural-historical potential).

- Accessibility and ancillary services (a general infrastructure which enables access to the destination, travelling to the attractions in the destination; also services used mainly by local inhabitants, such as telecommunication, medical and banking services).

- Amenities (superstructure and infrastructure of tourism that enable the stay in the destination and utilizing its attractions, for example accommodation, sportsrecreational, cultural-social facilities).

- Available packages (prepared products and product packages).

- Activities.

The characteristic components of destinations defined by Buhalis (2003) that are mentioned above indicate that in spite of the fact that service quality is primarily evaluated in terms of technical quality (the range of attractions and services), the destination assessment by functional quality aspects is necessary as well (Grönroos, 2007). Middleton and Clarke (2001) also use five components of the destination, three of which are the same as the components used by Buhalis (Attraction, Amenities, Accessibility) and the other two components are the image and perception of the destination and the price.

Although the literature is increasingly concerned with the issue of measuring the quality of tourist destinations, there are doubts among experts which of the methods that are available is of the highest validity. The main dispute appears to emerge between the supporters of the idea of measuring service quality as the difference between consumer expectations and services performance - introduced by Parasuraman et al. (1988) and called SERVQUAL - and the critics of their method suggest using the performance scale alone. The first experts to use SERVQUAL in tourism industry were for instance Saleh and Ryan (1991) or Baker and Fesenmaier (1997). Many researches (e.g. Knutson, 1991) adopted and modified SERVQUAL to specific industries and target groups. Brown et al. (1993) and Cronin and Taylor (1994) created an alternative to SERVQUAL called SERVPERF. Among the tools for researching the role of several features of a given product for a consumer importance-performance perception map presenting features of 
the destination's product on a two-dimensional graph (Zhang, Chow, 2004; Zemła, 2005) can be listed. Hill at al. (2003) study quality from the customer perspective as well. In their research, the authors use the method of PFI (Priority for Improvement) that is based on the gap analysis and the identification of customers' demands and wishes. According to Campo-Martanez and Garau-Vadell (2010), the measurement of overall satisfaction with the destination is based on the identification and assessment of key variables. It is necessary to find quality factors common to all destinations and to quantify these factors. The identification and evaluation of tourism competitiveness factors is a persistent long-lasting research problem of many scientific studies (Navickas, Malakauskaite, 2009). As stated by Hudson (2008) there is not a clearly recommended method that can be used to measure the quality of the tourism destination.

Theoretical formulations for the destination quality management (DQM) are included in the publication written by Woods and Deegan (2003). On the basis of their findings, the principles for the theoretical concept of DQM originated; these are the principles that are based on the tenets of necessity to meet basic standards of destination customers' minimum needs.

\section{Material and Methods}

The primary data that were necessary for meeting the determined objectives were obtained through questionnaire survey among the Czech Republic population ( $n=775$; quota sampling: gender, age). They were the respondents who had been rural tourism participants at least once in the past two years. The determination of rural tourism is approached in a systematic way according to Peláez (2004) who defines rural tourism as the activity of visitors which happens in the countryside and the main target of which is seeking areas that are attractive for tourists and that are related to relaxation, countryside, traditional culture and escape from crowds. As an unambiguous definition of the rural destination of tourism cannot be found in current literature, its general determination by Sharpley and Sharpley (1997) is used. The personal and electronic data were collected from the summer of 2015 to the spring of 2016.

The key questions of the questionnaire that are aimed at discovering the significance and performance of the research quality factors were formulated in the form of a five-point scale. The 19 factors that were evaluated in the questionnaire were formulated on the basis of the original research about the quality components of the destination (Buhalis, 2003; Middleton - Clarke, 2001) and on the basis of theoretical formulations for destination quality management presented by Woods and Deegan (2003). The research factors equally consider the functional and technical quality of services (Grönroos, 2007).

The following factors were researched:

1. Natural attractions (the conditions of natural character - for instance climate, hydrological and morphological circumstances, flora, fauna, water surfaces, caves, natural reservations).

2. Cultural and social attractions (for instance, castles, chateaus, galleries, museums, technical sights, religious monuments, historical city centres).

3. Accommodation (variety, the structure and level of accommodation facilities).

4. Food (variety, the structure and level of boarding facilities).

5. Social and experiential events (for example concerts, festivals, folk, sports and other events, local markets, seasonal gastronomical events such as wine harvests).

6. Availability of transportation to the destination (the accessibility of the destination, transport infrastructure, the frequency of transport links, distances between stops).

7. Local transportation (the possibilities of motorized and non-motorised transport around the destination, the conditions and equipment of the means of transport, the frequency and distances of stops from attractions, taxis, cyclobuses, ski lifts, cableways and so on).

8. Availability and quality of information in the destination (tourist information centres, maps, promotion materials, orientation boards, internet $-\mathrm{Wi}-\mathrm{Fi})$. 
9. Information and communication prior to arrival (the promotion and distribution of the destination offer, available and user-friendly unified web portal with topical destination offer that enables online reservations, prolinks to related websites, information on social networks and so on).

10. Friendly acceptance by the locals (atmosphere at the destination, friendly relationships towards visitors).

\section{Image of the destination.}

12. Level of prices of services and goods at the destination (the prices of consumer goods and services at the destination).

13. Level of personnel quality in tourism services - which means in accommodation and boarding services, information centres, transportation, guides and so on (their professionalism, empathy, willingness, reliability, credibility, opening hours, the effort to meet individual requirements of a client).

14. Sense of security (crime, terrorism, natural disasters, diseases, rescue and health system, security of sights, security of pedestrians or cyclists, safe background/attractions for children).

15. Destination cleanliness (natural environment, air, water for swimming, public toilets, enough waste bins, the cleanliness and maintenance of sights, the cleanliness of hospitality facilities).

16. Overcrowding of the destination (high concentration of visitors decreasing the quality of their stay, the capacity congestion of infrastructure, for example, car parks).

17. Uniqueness of destination (the uniqueness of the destination, local products, the differentiation of competitive offers, pre-prepared service packets, products of destination for various target segments, service certification).

18. Additional infrastructure (for example, sports equipment rental shops, cycle paths, cross country ski trails, hippo trails, aqua parks, playgrounds, entertainment centres, climbing centres, cash dispensers, background for motorists, cyclists, children).

19. Respecting sustainable development of the destination (the concordance of infrastructure construction with the natural environment of the destination, cultural heritage protection - for instance, protection of historical buildings, folklore and regional cuisine, natural environment protection, ecological economy, local inhabitants and businessmen involvement).

The Importance Performance analysis (IPA) was used to evaluate the quality level of rural destinations in the Czech Republic in the context of tourism. IPA is a tool that serves for the identification of the relative importance and performance of individual factors that have an impact on the observed quality. This method was first introduced by Martilla and James (1977) and it is the basic diagnostic and decisive tool (Matzler et al., 2003) that enables the identification of factors with the highest priority for improvements (Sampson, Showalter, 1999) and according to Levenburg and Magal (2004) for the mobilisation and development of the most demanded sources. The results of the IPA analysis are presented by means of two-dimensional graph displaying the values of the average importance on the vertical axis and the average performance on the horizontal axis. The axes divide the graph into four quadrants and according to the placement of the factors in individual quadrants following managerial decisions resulting in increasing the quality of services can be derived. The evaluated quality factors can then be divided into four following categories (Wong at al., 2011): Performance Shortfalls/Concentrate here; Key Features/Keep Up the Good Work; Low Priority Factors; Strategic Overkill/Possible Overkill.

Then the authors showed the possibility of reducing the 19 actual research factors into 6 dimensions that represent the quality of a rural destination. The Factor analysis (Osborne, 2009) was selected as a suitable method. At the beginning it was necessary to determine a suitable number of latent variables/dimensions of quality. The Principal Component Analysis was used 
where the number of dimensions then corresponds with the number of first principal components before the eigenvalues of principal components that express the level of data variability explained by principal components decreases.

The impact of the research quality factors on the customer's overall satisfaction with the rural destination and his or her loyalty towards the destination is then considered (multidimensional regression analysis) so that it is possible to evaluate the significance of the achieved quality dimensions of a rural destination. Loyalty is conceived according to Oppermann (2000) when the degree of visitors' loyalty to the destination is reflected in their intentions to revisit the destination and in their willingness to recommend it.

\section{Results}

\section{Quality factors significance}

The visitor's evaluation of individual quality factors importance for the rural destination of tourism can be seen in table 1; there is the significance order of the quality factors according to their perception by the visitor on the basis of 775 respondents' average evaluation on the scale of significance $1-5$, where the value of 5 represents a very high importance of the factor when evaluating the overall quality of the rural destination. On the contrary, the value of 1 expresses the minimal importance of the factor for the visitor.

To explore whether the evaluation of individual quality factors significance is dependent on the gender and age of the respondent/visitor to the destination non-parametrical Kruskal-Wallis test was used. The results of this dependency test are presented in Table 1. The value of YES+ means that the dependency of the factor on age or gender was proven on the $5 \%$ significance level of the test. The value of YES represents the proven dependency on the $10 \%$ significance level only. The value of NO says that the dependency was not even proven on the $10 \%$ level of significance and thus the attributed importance of the factor when evaluating the quality of the rural destination does not depend on the age or gender of the respondent.

In Table 1 mentioned above, it can be seen that the significance/importance of most research quality factors (13 factors; $68 \%$ ) does not depend on gender, and on the contrary the importance of 16 quality factors (84\%) depends on the age of the respondent. The highest importance is attributed to the factors of Destination cleanliness (4.52), Sense of security and Natural attractions, the attributed significance of which is not dependent on gender. However, in the case of these most important factors the dependency of the evaluation on the age of the respondents was proven ( $5 \%$ significance level). On the contrary, Local transportation is perceived as the least significant factor when evaluating the quality of the rural destination. The evaluation of this factor, similarly as in the case of the three most important factors mentioned above, depends on the age but not on the gender of the respondent.

\section{Evaluating the level of quality of the rural destination in the context of tourism}

The contents of this chapter present the results of evaluating the qualitative level of the rural destination from the perspective of a tourism participant. The quality of the destination is evaluated by means of the IPA analysis. In the following Table 2 , the average evaluation of the importance and performance of individual quality factors is compared. The factors are organized identically as in Table 1 (in the descending order from the highest significance for the respondent). The specific order according to the performance is presented in the last column of this table. The gap between the performance and the importance of the research quality factor can be seen in the third column of this table. This difference refers to the current strengths and weaknesses of the rural destination quality from the aspect of the rural tourism participant in the countryside. 
Tab 1. Evaluating the importance of the rural destination quality factors; the dependency of the evaluation on gender and age. Source: own research, 2015, $n=775$

\begin{tabular}{|c|c|c|c|c|c|c|}
\hline \multirow[b]{2}{*}{ Num. } & \multirow[b]{2}{*}{ Factor } & \multirow{2}{*}{ Mean } & \multicolumn{2}{|c|}{ KW-test SEX } & \multicolumn{2}{|c|}{ KW-test AGE } \\
\hline & & & $\begin{array}{c}\mathrm{p}- \\
\text { value }\end{array}$ & $\begin{array}{c}\text { Reject } \\
\mathrm{H}_{0}\end{array}$ & $\begin{array}{c}\mathrm{p}- \\
\text { value }\end{array}$ & $\begin{array}{c}\text { Reject } \\
\mathrm{H}_{0}\end{array}$ \\
\hline F15 & Destination cleanliness & 4.52 & .413 & NO & .000 & YES+ \\
\hline F14 & Sense of security & 4.42 & .816 & NO & .030 & YES+ \\
\hline $\mathrm{F} 1$ & Natural attractions & 4.36 & .452 & NO & .000 & YES+ \\
\hline F4 & Food & 4.29 & .126 & NO & .000 & YES+ \\
\hline F3 & Accommodation & 4.26 & .511 & NO & .000 & YES+ \\
\hline F12 & $\begin{array}{l}\text { Level of prices of services and goods in } \\
\text { the destination }\end{array}$ & 4.13 & .680 & NO & .017 & YES+ \\
\hline F13 & $\begin{array}{l}\text { Level of personnel quality in tourism } \\
\text { services }\end{array}$ & 4.11 & & NO & .000 & YES+ \\
\hline F10 & Friendly acceptance by the locals & 4.07 & .361 & NO & .000 & YES+ \\
\hline F6 & $\begin{array}{l}\text { Availability of transportation to the } \\
\text { destination }\end{array}$ & 4.02 & .061 & YES & .001 & YES+ \\
\hline F9 & $\begin{array}{l}\text { Information and communication prior to } \\
\text { arrival }\end{array}$ & 3.91 & .018 & YES+ & .000 & YES+ \\
\hline F8 & Availability and quality of information & 3.85 & .081 & YES & .000 & YES+ \\
\hline F19 & $\begin{array}{l}\text { Respecting sustainable development of } \\
\text { the destination }\end{array}$ & 3.79 & .999 & NO & .007 & YES+ \\
\hline$F 2$ & Cultural monument & 3.77 & .000 & YES+ & .113 & NO \\
\hline F5 & Social and experiential events & 3.68 & .534 & NO & .161 & NO \\
\hline F18 & Additional infrastructure & 3.67 & .280 & NO & .331 & NO \\
\hline F17 & Uniqueness of destination & 3.64 & .108 & NO & .083 & YES \\
\hline F16 & Overcrowding of the destination & 3.61 & .003 & YES+ & .002 & YES+ \\
\hline $\mathrm{F} 11$ & Image of the place & 3.51 & .020 & YES+ & .016 & YES+ \\
\hline F7 & Local transportation & 3.17 & .524 & NO & .000 & YES+ \\
\hline
\end{tabular}

The graphical interpretation of the IPA analysis (Table 2) is presented by Figure 2, which enables easier visual evaluation of the rural destination quality. This IPA analysis Fig. 2 was compiled on the basis of the average values of performance and importance of the research quality factors that are expressed in the relevant Table 2. The performance evaluated by means of the respondent's satisfaction with individual quality factors is presented by the average value of 4.01. The slightly lower value determined for the importance or the significance of the quality factors for the destination visitors is represented by the medium value of 3.94. These values create the centre of the coordinate system and the graph that enables to define four quadrants that divide the research factors into four groups in the context of destination quality management. 
Tab 2. The destination quality evaluation: performance - level of quality of the obtained service $(P)$, the importance of the research factor (I), the discovered gap (P-I). Source: own research, 2015, $n=775$

\begin{tabular}{|l|l|c|c|c|c|}
\hline Num. & \multicolumn{1}{|c|}{ Factor } & Perf. P & Import. I & $\begin{array}{c}\text { Difference } \\
\text { P - I }\end{array}$ & $\begin{array}{c}\text { Rank } \\
\text { Perf. }\end{array}$ \\
\hline F15 & Destination cleanliness & 4.29 & 4.52 & -0.23 & 3 \\
F14 & Sense of security & 4.33 & 4.42 & -0.08 & 1 \\
F1 & Natural attractions & 4.28 & 4.36 & -0.08 & 4 \\
F4 & Food & 4.20 & 4.29 & -0.10 & 6 \\
F3 & Accommodation & 4.23 & 4.26 & -0.03 & 5 \\
F12 & Level of prices of services and goods in the & & & & \\
F13 & destination & 4.03 & 4.13 & -0.10 & 8 \\
F10 & Friendly acceptance by the locals & 4.02 & 4.11 & -0.09 & 9 \\
F6 & Availability of transportation to the destination & 4.33 & 4.07 & 0.26 & 2 \\
F9 & Information and communication prior to arrival & 4.02 & 4.02 & 0.00 & 10 \\
F8 & Availability and quality of information & 3.96 & 3.91 & 0.11 & 11 \\
F19 & Respecting sustainable development of the & 3.85 & 0.11 & 12 \\
F2 & destination & 3.87 & 3.79 & 0.08 & 14 \\
F5 & Cultural monument & 3.92 & 3.77 & 0.15 & 13 \\
F18 & Additional infrastructure & 3.79 & 3.68 & 0.11 & 17 \\
F17 & Uniqueness of destination & 3.80 & 3.67 & 0.13 & 16 \\
F16 & Overcrowding of the destination & 3.81 & 3.64 & 0.17 & 15 \\
F11 & Image of the place & 3.68 & 3.61 & 0.08 & 18 \\
F7 & Local transportation & 4.09 & 3.51 & 0.57 & 7 \\
\hline
\end{tabular}

Quadrant I, in literature known as the performance deficit, is typical for the great significance of quality factors; nevertheless, they only achieve low performance. For the participant of tourism in the countryside, these factors are important but the satisfaction with their current level is insufficient. In Figure 2, it can be seen that in this top left quadrant no factors can be found. This can be considered to be a propitious situation as otherwise these factors would have to be paid priority attention leading to the increase of their level.

The items in quadrant II are perceived as optimal factors (Key Features/Keep Up the Good Work). The responders attach high significance to them and at the same time they evaluate their current qualitative level very positively. It is inevitable to continue working with the factors so that in the future the evaluated performance level will not deteriorate. Almost a half of the research factors (9) can be found in this quadrant: Natural attractions, Food, Accommodation, Availability of transportation to the destination, Friendly acceptance by the locals, Destination cleanliness, Sense of security, Level of prices of services and goods in the destination and Level of personnel quality in tourism services.

Quadrant III represents the category of low evaluated factors. However, the tourism participants attribute little significance to them. From the aspect of destination management and service providers in tourism, these are factors with a low priority for their care and maintenance. Due to the low importance of the factors, their low level of performance does not represent acute threat for the destination. Nevertheless, it is recommended not to underestimate the care of this category due to the strong competitive environment and the complex experience perception in tourism. Figure 2 shows the 8 factors pertaining to this category: Availability and quality of information, respecting sustainable development of the destination, Cultural monument, Social and experiential events, Additional infrastructure, Uniqueness of destination, Overcrowding of the destination and Local transportation. 
Fig 2. IPA analysis (Importance/Performance Analysis) of the rural destination. Source: own research, $n=775$

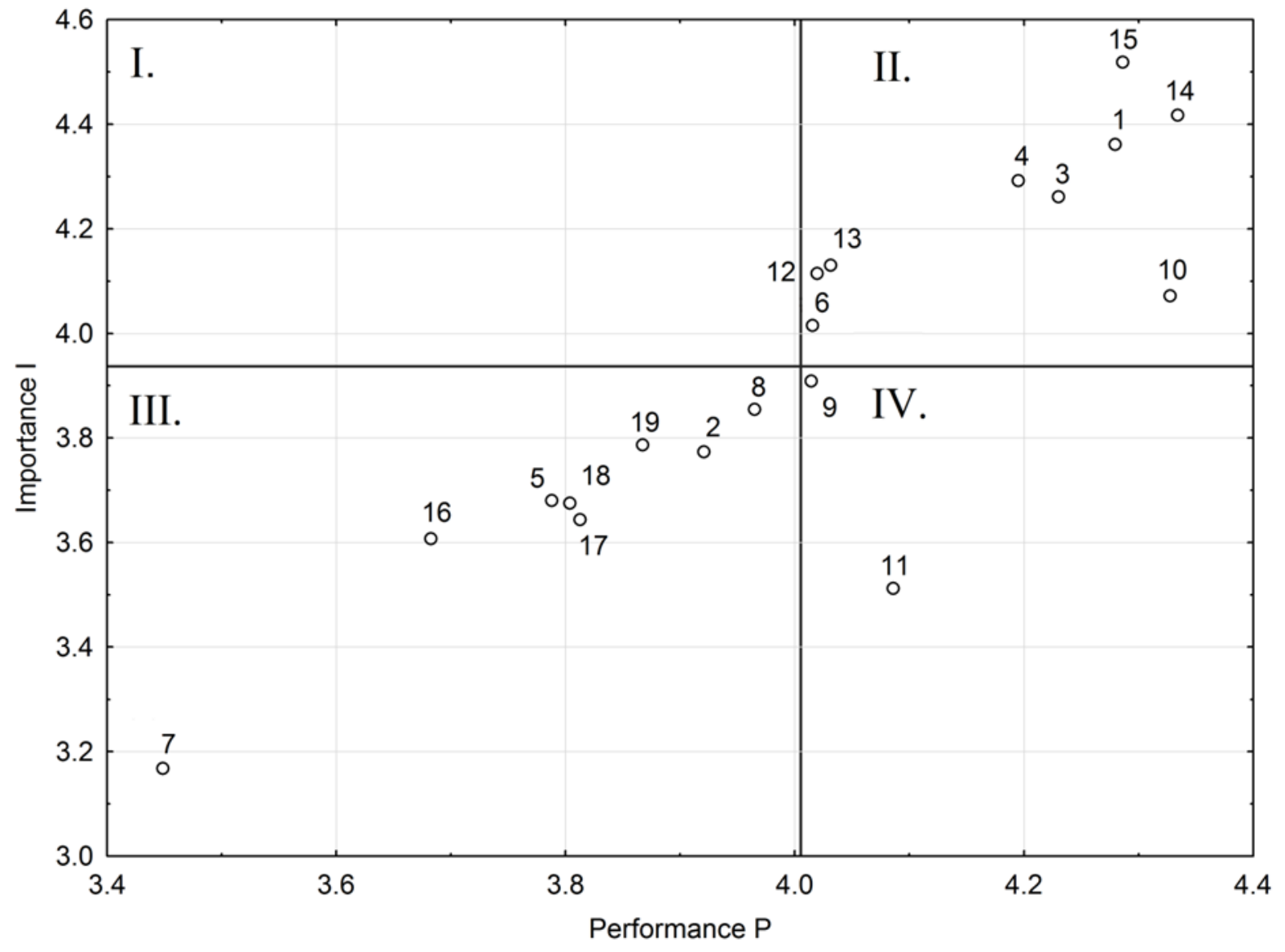

The relation of factors to the fourth category can be a signal for the management that they care too excessively of the factors that are less important for the clients. The qualitative level of these less important factors is highly evaluated by the respondents. Figure 2 shows that there are two quality factors in Quadrant IV: Information and communication prior to arrival, Image of the place. The detailed analysis of practical impacts of the IPA analysis results mentioned above is not the subject of this paper.

\section{Quality dimensions of the rural destination}

The authors also focus on determining the main dimensions of quality of the rural destination. By means of the factor analysis, they examined the possibility to reduce the current number of factors with the minimum loss of information - in other words, to find fewer groups among the 19 evaluated factors within the frame of which the evaluation of factors would be similar. These groups of factors are called "the dimensions of quality" and they are then logically named. The obtained quality dimensions can be considered to be the so-called latent variables that are not directly measurable but they become evident with the individual quality factors that belong to this group/dimension. Principal Component Analysis (PCA) was used to define the number of dimensions. As the decrease of eigenvalues of the main components expressed by the so-called Scree plot was not striking in this case (Figure 3), more options were tried to select the number of quality dimension. Another criterion that is often used for selecting the number of principal components is the choice of the principal components whose eigenvalues are higher than 1 or they at least approach 1. According to this perspective, 6 dimensions of quality were finally selected. They explain more than $65 \%$ variability of the 19 research quality factors. 
Fig 3. Scree plot in PCA. Source: own research, processed by STATISTICA software

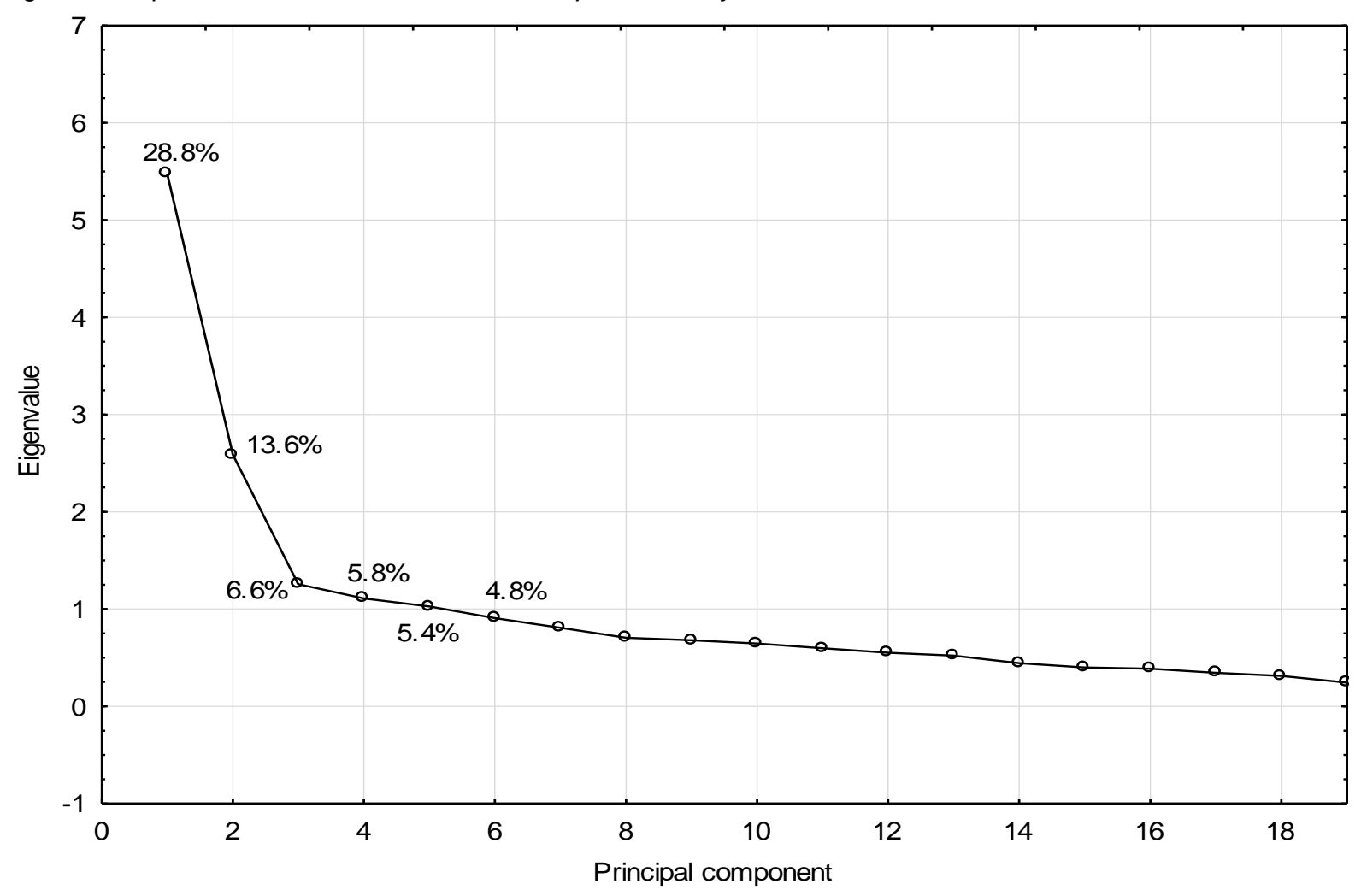

Tab 3. Factor loadings expressing the correlations of the research quality factors with the selected dimensions of the quality of a rural destination. Source: own research, $n=775$

\begin{tabular}{|c|c|c|c|c|c|c|c|}
\hline Num. & Factor & Dim.1 & $\operatorname{Dim} .2$ & Dim.3 & Dim.4 & Dim.5 & Dim.6 \\
\hline F1 & Natural attractions & -0.036 & 0.299 & -0.417 & -0.040 & 0.363 & 0.463 \\
\hline F2 & Cultural monument & 0.031 & 0.658 & -0.153 & -0.161 & 0.252 & -0.076 \\
\hline F3 & Accommodation & 0.715 & -0.135 & 0.002 & 0.362 & 0.211 & 0.118 \\
\hline F4 & Food & 0.758 & -0.062 & 0.049 & 0.378 & 0.124 & 0.088 \\
\hline F5 & Social and experiential events & 0.668 & 0.268 & 0.306 & -0.015 & 0.006 & 0.102 \\
\hline F6 & Availability of transportation to the destination & 0.279 & -0.210 & 0.546 & 0.414 & 0.127 & 0.218 \\
\hline F7 & Local transportation & 0.080 & 0.231 & 0.789 & -0.017 & 0.194 & 0.132 \\
\hline F8 & Availability and quality of information & 0.102 & 0.068 & 0.214 & 0.180 & 0.778 & 0.187 \\
\hline F9 & Information and communication prior to arrival & 0.162 & 0.170 & 0.033 & 0.183 & 0.787 & 0.111 \\
\hline F10 & Friendly acceptance by the locals & 0.002 & 0.098 & 0.240 & 0.594 & 0.347 & 0.029 \\
\hline F11 & Image of the place & 0.117 & 0.771 & 0.137 & 0.033 & 0.159 & -0.044 \\
\hline F12 & Level of prices of services and goods in the destination & 0.368 & -0.020 & 0.164 & 0.565 & 0.147 & -0.001 \\
\hline F13 & Level of personnel quality in tourism services & 0.354 & 0.113 & -0.022 & 0.612 & 0.357 & -0.089 \\
\hline F14 & Sense of security & 0.185 & -0.036 & 0.036 & 0.751 & 0.137 & 0.198 \\
\hline F15 & Destination cleanliness & 0.280 & 0.023 & -0.050 & 0.750 & 0.036 & 0.167 \\
\hline F16 & Overcrowding of the destination & -0.305 & 0.617 & 0.051 & 0.299 & 0.021 & 0.078 \\
\hline F17 & Uniqueness of destination & -0.029 & 0.742 & 0.113 & -0.017 & 0.004 & 0.313 \\
\hline F18 & Additional infrastructure & 0.261 & 0.097 & 0.168 & 0.097 & 0.223 & 0.731 \\
\hline \multirow[t]{3}{*}{ F19 } & Respecting sustainable development of the destination & 0.013 & 0.044 & 0.171 & 0.460 & 0.093 & 0.631 \\
\hline & Eigenvalue & 2.205 & 2.310 & 1.441 & 3.023 & 1.905 & 1.478 \\
\hline & Prop. Total Variability & 0.116 & 0.122 & 0.076 & 0.159 & 0.100 & 0.078 \\
\hline
\end{tabular}


As it was mentioned above, 6 dimensions entered the following factor analysis. To assign suitable quality factors to particular dimension, two methods were used: the extraction method - principal components and the factor rotation - varimax raw. Table 3 shows factor loadings that express the correlations of the original 19 research quality factors with the six selected dimensions. The highlighted values of factor loadings show the relations of the partial quality factors to the particular dimension. The last lines contain the eigenvalues of individual dimensions and their conversions to the percentage of the total variability explained by individual dimensions.

In the following list, the factors of quality are divided into the selected dimensions that are logically named. In the dimensions the factors are ranked from the most significant ones from the viewpoint of their average evaluation of importance for the visitors to the rural destination (see Table 1).

\section{Dimension 1: Services}

F3 Accommodation

F4 Food

F5 Social and experiential events

Dimension 2: Image

F2 Cultural monuments

F17 Uniqueness of destination

F16 Overcrowding of the destination

F11 Image of the place

\section{Dimension 3: Transportation}

F6 Availability of transportation to the destination

F7 Local transportation

\section{Dimension 4: Well-being}

F15 Destination cleanliness

F14 Sense of security

F12 Level of prices of services and goods in the destination

F13 Level of personnel quality in tourism services

F10 Friendly acceptance by the locals

Dimension 5: Information/Communication

F9 Information and communication prior to arrival

F8 Availability and quality of information

\section{Dimension 6: Attractions/Experiences}

\section{F1 Natural attractions \\ F18 Additional infrastructure \\ F19 Respecting sustainable development of the destination}

In the first dimension called 'Services', the highest evaluation was reached by the factors Accommodation and Food that took the fourth and the fifth place among all the 19 evaluated factors. The factor of Social and experiential events that does not achieve such a high evaluation can appear in this group, for instance due to the fact that the experiences during visits to rural destinations are very often connected with gastronomical experiences or with the uniqueness of accommodation. 
The second dimension called "Image" is represented by factors with rather low average evaluations of their significance for the visitor to the destination. The factor of Cultural monuments, which is the most important within the dimension, took only the $13^{\text {th }}$ place out of the 19 research factors. From this point of view, this dimension of quality can be considered as the least significant, in spite of the fact that the differences in the average evaluation within all the factors are not considerable (see Table 1).

The third dimension of "Transportation" is represented by only two factors that are semantically different. In Table 1, it is possible to see a significant difference in evaluating the importance of the factor concerning the transport to the destination (4.02) in comparison to the local transportation (3.17), which came last in the order of the observed factors.

The fourth dimension is called "Well-being" and it concerns the comfort/friendliness/ hospitality of the destination. In the context of the average evaluation of the factor significance for the visitor, this dimension can be undoubtedly considered to be the most important. The related factors of Destination cleanliness and Sense of security took the first two positions and the other factors of this dimension (F12, F13, F10) can also be found at the front positions in the overall evaluation of the importance of the rural destination research factors (see Table 1).

The fifth dimension of "Information/Communication" is related to the quality and friendliness of the communication in the destination and also sufficient information on the destination. The related factors of F9 and F8 came closely in the second half of the average evaluation of all 19 factors. This minor significance of this dimension in comparison to the others can originate from the fact that the good level of awareness, knowledge and communication are considered to be obvious in present times.

The sixth dimension of "Attractions/Experiences" is very significant in the frame of rural tourism. The most important factor of this dimension is "Natural attractions" (the third place in the overall order of significance, see Table 1). The other factors (F18, F19) do not achieve such importance; nevertheless, they can be considered to be logical and justified supplementation of this dominant factor. The factor of Respecting sustainable development of the destination achieved a significantly higher evaluation of importance for the visitor to the destination (3.79) in comparison to the results of the research aimed at urban destinations (3.20; Rasovska et al., 2016) or the research without the relation to a specified type of a tourism destination (3.17; Ryglova et al., 2015). Thus this fact supports the consideration mentioned above.

\section{Discussion}

The results of the research above can be utilized to manage the satisfaction of the visitor to the destination more efficiently in the context of quality management. The IPA analysis mentioned above occupies an important position among the methods for evaluating service quality by means of customer satisfaction, and so does the SERVQUAL model that was developed in the USA in 1988 (Parasuraman et al., 1988). These authors introduced five dimension of service quality that have an impact on the customer's comprehension of a quality service, ordered according to their importance. SERVQUAL focuses on the performance of the model components of "service quality" where quality is defined as the difference between the expectations and the actual performance. The model has been improved and revised several times, and the development has also shown the influence of a specific branch or cultural differences on the importance of quality dimensions (e.g. Zeithaml, Bitner, 2000; Zeithaml et al., 1996, 2006).

Due to the reasons mentioned above, the authors of this paper considered the idea of possible determination of actual significance of the obtained quality dimensions of the rural destination. The following Table 4 shows the order of the dimensions according to the average evaluation of the importance of all the relevant quality factors as seen by the visitor to the destination (the first column) while the second column of this table shows the average evaluation of the most important factor in the dimension. 
Tab 4. The importance of the selected quality dimension of the rural destination according to the respondent's evaluation of significance.

\begin{tabular}{|l|l|l|}
\hline Dimension & Mean & Max \\
\hline Well-being & 4.25 & $4.52(\mathrm{~F} 15)$ \\
Services & 4.08 & $4.29(\mathrm{~F} 3)$ \\
Attractions/Experiences & 3.94 & $4.36(\mathrm{~F} 1)$ \\
Information/Communication & 3.88 & $3.91(\mathrm{~F} 9)$ \\
Image & 3.63 & $3.77(\mathrm{~F} 2)$ \\
Transportation & 3.59 & $4.02(\mathrm{~F} 6)$ \\
\hline
\end{tabular}

If the order of importance of individual dimensions is assessed from the viewpoint mentioned above, which means according to the average evaluation of the importance of the partial factor by the visitor to the destination, the first three positions are taken by the dimensions of "Wellbeing", "Services" and "Attractions/Experiences" where the dimension of "Well-being" is conclusively the most significant.

The subject of the further research was the effort to explore the importance of individual quality dimensions according to the influence of the relevant quality factors on the overall satisfaction of the visitor to the destination and the loyalty towards the destination. The regression models were used for this purpose. This is why it was inevitable to discover the level of the overall satisfaction in the destination and the loyalty towards the destination (see table 5).

Tab 5. Average values for the overall satisfaction and loyalty towards the destination. Source: own research, $n=775$, Likert 5-point scale

\begin{tabular}{|l|r|}
\hline L-R (loyalty-reference) & 4.47 \\
L-C (loyalty-revisit) & 4.34 \\
T S (total satisfaction) & 4.53 \\
\hline
\end{tabular}

The following Table 6 shows the list of the research quality factors that have an influence on the overall satisfaction in the destination. They are ordered according to their influence on the overall satisfaction beginning with the most influential factor.

Tab 6. The order of the factors according to their influence on the overall satisfaction in the rural destination. Source: own research, $n=775 ; R^{2}=0.250 ; 10 \%$ significance level

\begin{tabular}{|l|l|c|c|c|}
\hline Mark & Factor & Dim. & Reg. coef. & P-value \\
\hline const & & & 1.944 & $5.13 \mathrm{E}-29$ \\
F1 & Natural attractions & 6 & 0.136 & $3.03 \mathrm{E}-06$ \\
F15 & Destination cleanliness & 4 & 0.132 & $2.42 \mathrm{E}-05$ \\
F3 & Accommodation & 1 & 0.091 & 0.0021 \\
& Level of prices of services and goods in the & 4 & & \\
F12 & destination & 4 & 0.081 & 0.0205 \\
F10 & Friendly acceptance by the locals & 2 & 0.075 & 0.0164 \\
F11 & Image of the place & 1 & 0.043 & $4.57 \mathrm{E}-02$ \\
F5 & Social and experiential events & & & \\
\hline
\end{tabular}

The overall satisfaction in the rural destination is influenced the most by the factors of Natural attractions (F1) and Destination cleanliness (F15). According to the regression coefficient (see Table 6), the level of the impact of the particular factor on the overall satisfaction in the destination can be assessed. For instance, the increase in evaluating the satisfaction with the natural attractions by one point results in the increase in evaluating the overall satisfaction by 0.136 points 
on average. This model explains $25 \%$ of the variability of the overall satisfaction in the destination. In this table, the dimensions of quality that are described above are assigned to the statistically significant factors that belong to these dimensions. Based on the factor affiliation to the particular dimension, it is possible to evaluate the performance, that is, which dimension of quality influences the overall satisfaction with the destination the most significantly; in other words, the significance of the dimensions. The dimension 4 (Well-being) is undoubtedly the most influential. It is represented by three factors (F15, F12 and F10) in the regression model. The importance of the factor of "Friendly acceptance by the locals" corresponds with the results of the study by do Valle et al. (2011) where the author compared four destinations in Portugal and on the basis of this example, it was proven that the positive approach and acceptance from the side of local inhabitants significantly influences the overall satisfaction of the tourists in the destination. The following in the table are the dimension 6 (Attractions/Experiences) and the dimension 1 (Service). The last dimension that is statistically important is the dimension 2 (Image). The dimensions 3 and 5 do not appear in the regression model.

This order of the dimensions is very similar to the order according to the significance attributed by the respondent (Table 4). The only deflection is represented by the dimension of Image that takes last positions of importance from the aspect of significance. Nevertheless, the impact of this dimension on the overall satisfaction of the visitor to the destination was statistically verified, which is presented by Middleton and Clarke (2001) or Coban (2012) in their studies.

The following Table 7 and Table 8 provide the list of quality factors that have an impact on the visitor's loyalty towards the rural destination. They are ordered with respect to their influence on the loyalty from the most influential factor as the first. The visitor's loyalty towards the destination was assessed on the basis of two criteria: a) whether the visitor is planning to revisit the destination, b) whether the visitor is going to spread positive recommendations and references about the destination.

Tab 7. The order of the factors according to their influence on the loyalty toward the rural destination (revisit to the destination). Source: own research, $n=775 ; R^{2}=0.207,10 \%$ significance level

\begin{tabular}{|l|l|c|c|c|}
\hline Mark & Factor & Dim. & Reg. coef. & P-value \\
\hline const & & & 1.625 & $6.48 \mathrm{E}-15$ \\
F10 & Friendly acceptance by the locals & 4 & 0.150 & 0.0001 \\
F15 & Destination cleanliness & 4 & 0.133 & 0.0006 \\
F11 & Image of the place & 2 & 0.121 & 0.003 \\
F1 & Natural attractions & 6 & 0.100 & 0.0076 \\
F3 & Accommodation & 1 & 0.089 & 0.0155 \\
F17 & Uniqueness of destination & 2 & 0.075 & 0.0281 \\
\hline
\end{tabular}

The influence of the performance of the quality factors on the repeated visit to the destination can be seen in Table 7 . This model explains $21 \%$ of variability, which is less than in the previous model of the overall satisfaction and therefore it can be claimed that the quality factors influence the revisit to the destination to a lower extent than the evaluation of overall satisfaction with the destination. From the aspect of the impact of quality dimensions on the explained variable, the situation is similar to the previous model of the overall satisfaction. The order of the dimensions according to their significance is as follows: 1. Well-being, 2. Image, 3. Attractions/Experiences, 4. Services. The fact that deserves our attention is that in this model the dimension of Image achieves even a higher influence on loyalty and the possibility of revisit than on the overall satisfaction with the destination. 
Tab 8. The order of the factors according to their influence on the loyalty towards the rural destination (positive references/recommendation). Source: own research, $n=775 ; R^{2}=0.265 ; 10 \%$ significance level

\begin{tabular}{|l|l|c|c|c|}
\hline Mark & Factor & Dim. & Reg. coef. & P-value \\
\hline const & & & 1.523 & $2.40 \mathrm{E}-16$ \\
F1 & Natural attractions & 6 & 0.149 & $3.73 \mathrm{E}-06$ \\
F14 & Sense of security & 4 & 0.098 & 0.0097 \\
F11 & Image of the place & 2 & 0.095 & 0.0067 \\
F17 & Uniqueness of destination & 2 & 0.087 & 0.0031 \\
F3 & Accommodation & 1 & 0.072 & 0.0262 \\
F10 & Friendly acceptance by the locals & 4 & 0.070 & 0.0446 \\
F15 & Destination cleanliness & 4 & 0.069 & 0.064 \\
F12 & Level of prices of services and goods in the & 4 & 0.066 & 0.0878 \\
\hline
\end{tabular}

The results of the regression model that explains the influence of quality factors on the loyalty by means of spreading positive references and recommending the destination can be seen in Table 8. This model explains more than $26 \%$ variability, which represents the highest percentage of the models described above. The importance of the dimensions of quality on the basis of this model confirms the previous results (Table 7); the order of the dimensions is almost identical to the previous model. The obtained results correspond with the research by Meng et al. (2008) which revealed that destination quality does not only concern outdoor activities and natural scenery but it is also dependent on the provision of elements such as friendly service and quality lodging facilities. The regression models mentioned above were evaluated by means of $\mathrm{F}$-test as statistically significant. They were also compared to more complex models (e.g. lin-log model). However, they did not provide better results and all the presumptions of the linear regression model were tested.

\section{Conclusions}

The specific character of the services is responsible for indefinite approaches to the interpretation and evaluation of their quality that requires the examination of quality factors in different sectors. The identification and significance of the factors of quality related to competitiveness is the topic of examination of a number of research studies, but these studies are mostly focused on the evaluation of quality in partial areas of the tourist industry (e.g. Thruong, Foster; 2006; Hsieh et al. 2008; Martin-Cejas, 2006; Chitty et al. 2007; Zhu, Zhao; 2010). Research studies that concentrate on the evaluation of the quality of the destination as a comprehensive product of the tourist industry are less frequent (e.g. Kresic, Prebezac 2011; Xielong, 2011; Zabkar et al., 2010).

The visitors' perceptions of the quality of the tourism destination are fundamental for effective destination management and marketing. The objective of the authors was to present the results of the research that focuses on exploring the problems of perceiving quality in the rural destination, to identify crucial factors and dimensions of quality and to discover the factors that influence the overall satisfaction and loyalty towards the destination.

The conducted research identified six topical dimensions of quality of the rural destination: Wellbeing, Services, Attractions/Experiences, Information/Communication, Image and Transportation. The dimension of Well-being was discovered as the most significant. This dimension reflects the demands of the visitors and participants of tourism on the cleanliness of the destination, security and the friendly approach and acceptance by local inhabitants or local entrepreneurs, which is also reflected in keen and friendly prices for the provided services and products. The importance of the rural destination quality and the visitors' requirements for natural attractions, image and the uniqueness of the destination resound in the results significantly. Concurrently, the influence of the image of the place on the overall satisfaction and the loyalty towards the destination was proven as well. 
When comparing the obtained quality dimensions for the rural area with the similar research aimed at the urban type of the destination (Rasovska et al., 2016), the congruence can be found in the dimensions of Service, Image, Transportation and Well-being, where the quality of provided services in the dimension of Services followed by the dimension of Image appears to be the most significant for the visitors to urban destinations.

The paper contains the application of IPA that evaluates the perceived qualitative level of the rural destination in the Czech Republic. In spite of the fact that IPA is often a subject of polemics concerning practical problems of its utilization, such as setting measurable variables, direct or indirect importance measuring, the IPA graph construction, the statistical treatment of data (Oh, 2001; Bacon, 2003; Abalo et al., 2007), the authors agree in their conclusions and they recommend IPA as a suitable research tool in the area of tourism. On the basis of IPA, it is possible to identify the crucial contradictions between actually obtained performance (the perceived quality of the obtained service) and the attributed importance of research factors in rural areas in the Czech Republic. The IPA analysis can be recommended especially due to the uncomplicated availability of input data and the possibility to express the results graphically and illustratively, which enables the practical interpretation of the obtained results that concern the qualitative level of the evaluated destination.

In similar types of areas, the research results/the revealed key factors of quality and their importance can simplify the practical application of scientific methods (e.g. SERVQUAL, SERVPERF, IPA, PFI) by means of methodological approach/measurable variables. The findings can also serve as input data for these methods that enable the evaluation of the actual qualitative level of the destination.

The research findings contribute to broadening the current theory and studies with the topical destination quality dimensions that reflect contemporary environment development and to better understanding of the behavioural mechanism in rural areas and can be used by destination managers and services providers to increase the efficiency of quality management to improve their competitiveness.

\section{Acknowledgements}

The results presented in this paper are part of the project No. 15-21179S 'The Quality Evaluation of Tourism Destination', which is conducted with the support of Grant Agency of the Czech Republic.

\section{Academic references}

[1] Abalo, J., Varela, J. \& Manzano, V. (2007). Importance values for importance-performance analysis: a formula for spreading out values derived from preference rankings. Journal of Business Research 60(2), 115-121. DOI: 10.1016/j.jbusres.2006.10.009.

[2] Bacon, D. R. (2003). A comparsion of approaches to Importance-Performance Analysis. International Journal of Market Research, 45(1), 55-71.

[3] Baker, D. A. \& Crompton, J. L. (2000). Quality, satisfaction and behavioral intentions. Annals of Tourism Research 27(3), 785-804. DOI: 10.1016/S0160-7383(99)00108-5.

[4] Baker, D. \& Fesenmaier, D. (1997). Effects of service climate on managers'and employees' rating of visitors' service quality expectations. Journal of Travel Research, 36(1), 15-22. DOI: 10.1177/004728759703600103.

[5] Bieger, T. (2008). Management von Destinationen. $7^{\text {th }}$ ed. München: Oldenburg Wissenschaftsverlag.

[6] Brown, T., Churchil, G. \& Peter, P. (1993). Improving the Measurement of Service Quality. Journal of Retailing, 69(1) 127-139. DOI: 10.1016/S0022-4359(05)80006-5. 
[7] Buhalis, D. (2003). eTourism: Information technology for Strategic Tourism Management. Prentice Hall, London: Pearson.

[8] Campo-Martanez, P. \& Garau-Vadell, J. B. (2010). The generation of tourism destination satisfaction. Tourism Economics, 16(3). 461-475. DOI: 10.5367/000000010792278383.

[9] Coban, S. (2012). The Effects of the Image of Destination on Tourist Satisfaction and Loyalty: The Case of Cappadocia. European Journal of Social Science, 29(2), 222-232.

[10] Court, B. C. \& Lupton, R. A. (1997). Customer portfolio development: Modeling destination adopters, inactives, and rejecters. Journal of Travel Research, 36(1), 35-43. DOI: $10.1177 / 004728759703600106$.

[11] Cronin, J. \& Taylor, P. (1994). SERVPERF versus SERVQUAL: Reconciling performancebased and perceptions-minus-expectations measurement of service quality. Journal of Marketing 58(1), 125-131. DOI: 10.2307/1252256.

[12] Cronin, J. J., Brady, M. K. \& Hult, G. T. M. (2000). Assessing the effects of quality, value, and customer satisfaction on consumer behavioral intentions in service environments. Journal of Retailing 76(2), 193-218. DOI: 10.1016/S0022-4359(00)00028-2.

[13] Do Valle, P., Mendes, J., Guerreiro, M. \& Silva, J., (2011). Can welcoming residents increase tourist satisfaction? Anatolia: An International Journal Of Tourism \& Hospitality Research 22(2), 260-277. DOI: 10.1080/13032917.2011.593915.

[14] Gronroos, C. (2007). Service Management and Marketing: Customer Management in Service Competition. $3^{\text {rd }}$ rev. ed. New York: John Wiley \& Sons.

[15] Hill, N., Brierley, J. \& MacDougall, R. (2003). How to measure customer satisfaction. $2^{\text {nd }}$ ed. Abingdon: Routledge.

[16] Hsieh, L., Lin, L. \& Lin, Y. (2008). A service quality measurement architecture for hot spring hotels in Taiwan. Tourism Management 29(3), 429-438. DOI: $10.1016 /$ j.tourman.2007.05.009.

[17] Hudson, S. (2008). Tourism and Hospitality marketing. $1^{\text {st }}$ ed. London: SAGE.

[18] Chi, C. G. \& Qu, H. (2007). Examining the structural relationships of destination image, tourist satisfaction and destination loyalty: An integrated approach. Tourism Management 29(4), 624-636. DOI: 10.1016/j.tourman.2007.06.007.

[19] Chitty, B., Ward, S. \& Chua, A. CH. (2007). An application of the ECSI model as a predictor of satisfaction and loyalty for backpacker hostels. Marketing Intelligence and Planning 25(6), 563-580. DOI: 10.1108/02634500710819941.

[20] Cho, B. H. (2000). Destination. In Encyklopedia of Tourism (pp. 144-145). Abingdon/New York: Routledge.

[21] Kim, A. K. \& Brown, G. (2012). Understanding the relationships between perceived travel experiences, overall satisfaction, and destination loyalty. Anatolia - An International Journal of Tourism and Hospitality Research 23(3), 328-347. DOI: 10.1080/13032917.2012.696272.

[22] Knutson, B., Stevens, P., Wullaert, C., Patton, M. \& Yokoyama, F. (1991). LODGSERV: A service quality index for lodging industry. Hospitality Research Journal 14(2), 277-284. DOI: $10.1177 / 109634809001400230$.

[23] Kresic, D., Prebezac, D. (2011). Index of destination attractiveness as a tool for destination attractiveness assessment. Turizam: znanstveno-stručni časopis. Vol. 59 No 4/ 2011/497517.

[24] Levenburg, N. M. \& Magal, R. S. (2004). Applying Importance-Performance Analysis to Evaluate E-Business Strategies among Small Firms. E-Service Journal 3(3), 29-48.

[25] Marakova, V. (2015). Development of geoparks as tourism products (comparative analysis Slovakia and Germany). In SGEM215 Conference Proceeding (pp. 139-148). Sofia: STEF92 Technology Ltd. DOI: 10.5593/SGEM2015/B52/S20.019. 
[26] Martilla, J. A. \& James J. C. (1977). Importance-performance analysis. Journal of Marketing, 41(1), 77-79. DOI: 10.2307/1250495.

[27] Martin-Cejas, R. R. (2006). Tourism service quality begins at the airport. Tourism Management 27(5), 874-877. DOI: 10.1016/j.tourman.2005.05.005.

[28] Matzler, K., Sauerwein, L. \& Heischmidt, K. A. (2003). Importance-performance analysis revisited: the role of the factor structure of customer satisfaction. The Service Industries Journal 23(2), 112-129. DOI: 10.1080/02642060412331300912.

[29] Meng, F., Tepanon, Y. A. \& Uysal, M. (2008). Measuring tourist satisfaction by attribute and motivation: The case of a nature-based resort. Journal of Vacation Marketing 14(1), 41-56. DOI: $10.1177 / 1356766707084218$.

[30] Middleton, V. T. C. \& Clarke, J. R. (2001). Marketing in travel and tourism. $3^{\text {rd }}$ ed. Boston: Butterworth-Heinemann.

[31] Navickas, V. \& Malakauskaite, A., (2009). The Possibilities for the Identification and Evaluation of Tourism Sector: Competitiveness factors. Engineering Economics 61(1), 3744.

[32] Oh, H. (2001). Revisiting importance-performance analysis. Tourism Management 22(6), 617-627. DOI: 10.1016/S0261-5177(01)00036-X.

[33] Oppermann, M. (2000). Tourism destination loyalty. Journal of Travel Research 39(1), 7884. DOI: $10.1177 / 004728750003900110$.

[34] Osborne, J. \& Costello, A. B. (2009). Best practices in exploratory factor analysis: Four recommendations for getting the most from your analysis, Pan-Pacific Management Review 12(2), 131-146.

[35] Parasuraman, A., Zeithaml, V. \& Berry, L. (1988). SERVQUAL: A Multiple-Item Scale for Measuring Consumers Perception of Service Quality. Journal of Retailing, 64(1), 12-40.

[36] Peláez, L. V. (2004). Rural tourism: A diversifying alternative. Strategic lines of its expansion. Papeles de Economía Española 102, 298-315.

[37] Rašovská (Vajcnerová), I., Ryglová, K. \& Sacha, J. (2016). The dimensions and quality factors in urban destinations. Czech Hospitality and Tourism Papers. 2016. sv. 12, č. 27 , p. 19-27. ISSN 1801-1535.

[38] Ryglova, K., Vajcnerova, I., Sacha, J. \& Strojarova, S. (2015). The Quality as a Competitive Factor of the Destination. Procedia Economics and Finance 34, 550-556. DOI: 10.1016/S2212-5671(15)01667-6.

[39] Saleh. F. \& Ryan, C. (1991). Analyzing service quality in the hospitality industry using SERVQUAL model. Service Industries Journal 11(3), 324-345. DOI: 10.1080/02642069100000049.

[40] Sampson, S. E. \& Showalter, M. J. (1999). The performance-importance response function: observations and implications. The Service Industries Journal 19(3), 1-25. DOI: $10.1080 / 02642069900000027$.

[41] Sharpley, S. \& Sharpley, J. (1997). Rural Tourism: An Introduction. London: International Thomson Business Press.

[42] Šimková, E. (2008). Manažerské a marketingové přistupy ve venkovské turistice. Hradec Králové: Gaudeamus.

[43] Sonmez, S. F. \& Graefe, A. R. (1998). Determining future travel behavior from past travel experience and perceptions of risk and safety. Journal of Travel Research 37(2), 171-177. DOI: $10.1177 / 004728759803700209$.

[44] Taylor, S. A. \& Baker T. L. (1994). An Assessment of the Relationship between Service Quality and Customer Satisfaction in the Formation of Consumers' Purchase Intentions. Journal of Retailing 70(2), 163-178. DOI: 10.1016/0022-4359(94)90013-2. 
[45] Thruong, T. H. \& Foster, D. (2006). Using HOLSAT to evaluate tourist satisfaction at destinations: The case of Australian holidaymakers in Vietnam. Tourism Management 27(5), 842-855. DOI: 10.1016/j.tourman.2005.05.008.

[46] Wong, M., Hideki, N. \& George, P. (2011). The Use of Importance-Performance Analysis in Evaluating Japan's E-government Services. Journal of Theoretical and Applied Electronic Commerce Research 6(2), 17-30. DOI: 10.4067/S0718-18762011000200003.

[47] Woods, M. \& Deegan, J. (2003). A Warm Welcome for destination quality brands: the example of the Pays Cathare region. International Journal of Tourism Research 5, 269282. DOI: $10.1002 /$ jtr.436.

[48] Xielong, X. (2011). Service quality Measurement from Customer Perception Based on Services Science, Management and Engineering. Systems Engineering Procedia. 1, 337343. DOI: 10.1016/j.sepro.2011.08.051.

[49] Yuksel, A. Yuksel, F. \& Bilim, Y. (2010). Destination attachment: effects on customer satisfaction and cognitive, affective and conative loyalty. Tourism Management 31(2), 274284. DOI: 10.1016/j.tourman.2009.03.007.

[50] Žabkar, V., Brenčič, M. M. \& Dmitrović, T. (2010). Modelling perceived quality, visitor satisfaction and behavioural intentions at the destination level. Tourism Management 31(4), 537-546. DOI: 10.1016/j.tourman.2009.06.005.

[51] Zeithaml, V. A., Berry, L. L. \& Parasuraman, A. (1996). The behavioural consequences of service Quality. Journal of Marketing, 60(2), 31-46. DOI: 10.2307/1251929.

[52] Zeithaml, V. A. \& Bitner, M. J. (2000). Services Marketing: Integrating customer focus across the firm. $2^{\text {nd }}$ ed. Boston: Irwin/ McGraw-Hill.

[53] Zeithaml, V. A., Bitner, M. J. \& Gremler, D. (2006). Services marketing: integrating customer focus across the firm. $4^{\text {th }}$ ed. Boston: McGraw-Hill/Irwin.

[54] Żemla, M., (2005). Application of importance-performance perception maps in major Polish ski resorts product quality analysis. Hotellink 6(6), 275-284.

[55] Zhang, H. Q. \& Chow, I. (2004). Application of importance performance model in tour guides' performance: evidence from mainland Chinese outbound visitors in Hong Kong. Tourism Management 25(1), 81-91. DOI: 10.1016/S0261-5177(03)00064-5.

[56] Zhu, X. N. \& Zhao, S. R. (2010). Research on Evaluation of Tourism Public Service from the Perspective of Tourist Satisfaction. Proceedings of 2010 International Conference on Public Administration (pp. 643-648). Chengdu: University of Electronic Science and Technology. 